\title{
Novel Complexing Agents for the Efficient Separation of Actinides and Remediation of Actinide-Contaminated Sites
}

RECEIVED

Patricia Baisden

Babak Kadkhodayan

MAY 02 19S

OSTI

March 15, 1996

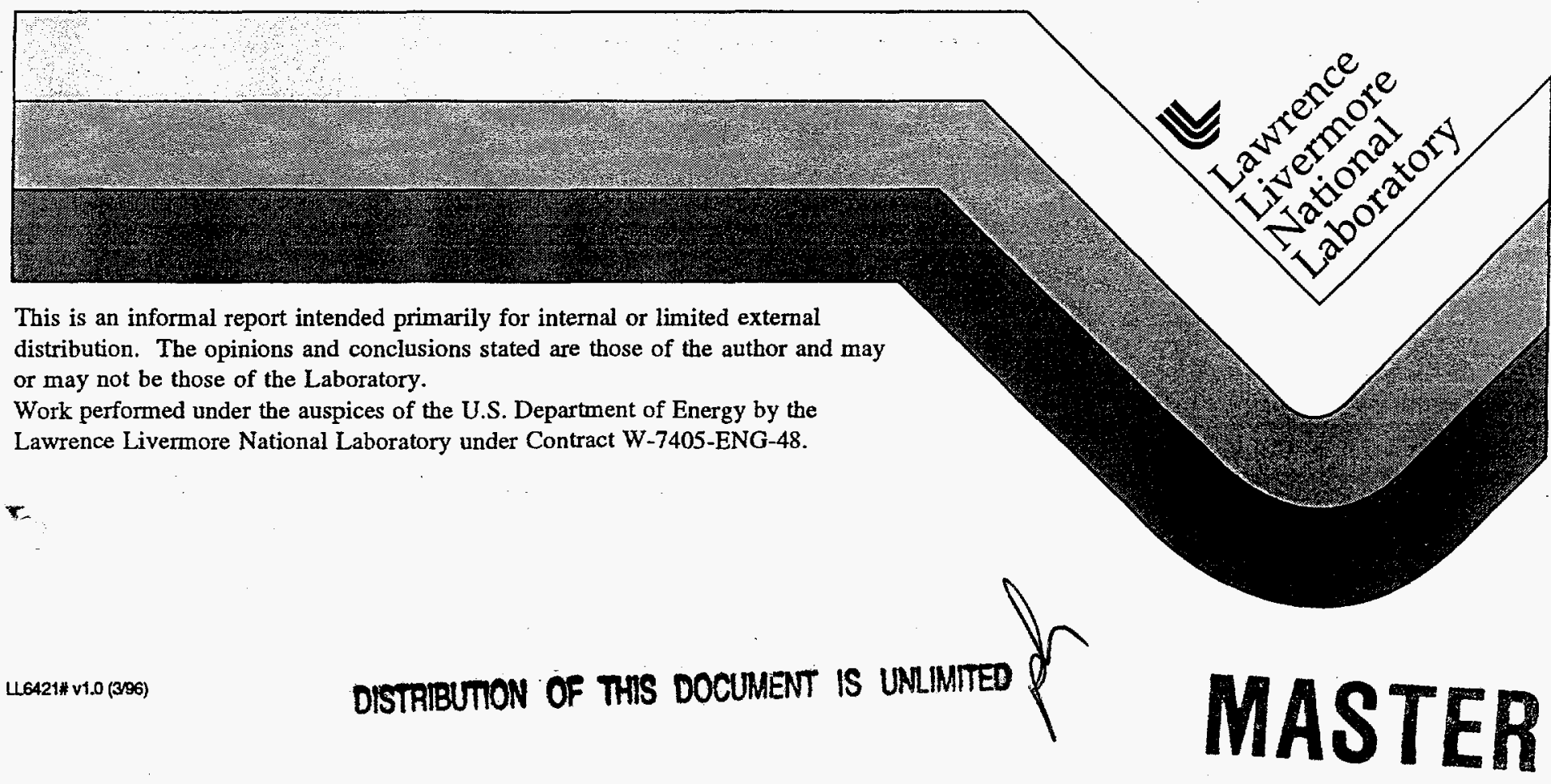




\section{DISCLAIMER}

This document was prepared as an account of work sponsored by an agency of the United States Government. Neither the United States Government nor the University of California nor any of their employees, makes any warranty, express or implied, or assumes any legal liability or responsibility for the accuracy, completeness, or usefulness of any information, apparatus, product, or process disclosed, or represents that its use would not infringe privately owned rights. Reference herein to any specific commercial products, process, or service by trade name, trademark, manufacturer, or otherwise, does not necessarily constitute or imply its endorsement, recommendation, or favoring by the United States Government or the University of California. The views and opinions of authors expressed herein do not necessarily state or reflect those of the United States Government or the University of California, and shall not be used for advertising or product endorsement purposes.

This report has been reproduced directly from the best available copy.

Available to DOE and DOE contractors from the Office of Scientific and Technical Information P.O. Box 62, Oak Ridge, TN 37831

Prices available from (615) 576-8401

Available to the public from the National Technical Information Service

U.S. Department of Commerce 5285 Port Royal Rd., Springfield, VA 22161 


\title{
Novel Complexing Agents for the Efficient Separation of Actinides and Remediation of Actinide-Contaminated Sites
}

\author{
Patricia Baisden, Principle Investigator \\ Babak Kadkhodayan, Co-Investigator \\ Glenn T. Seaborg Institute for Transactinium Science \\ Lawrence Livermore National Laboratory
}

Research into the coordination chemistry of transactinide elements should provide us with new fundamental knowledge about structure, geometry, and stability of these metal complexes. Our approach involves the design, synthesis, and characterization of "expanded porphyrin" macrocyclic ligands which coordinate the actinide metal cations with high thermodynamic affinity and kinetic stability. We can use the knowledge from understanding the fundamental coordination chemistry of these elements as a stepping stone to heavy metal detoxification, radioactive waste cleanup, and possibly radioactive isotope separation. The critical components of this research endeavor, along with the viability of metal complex formation, will be correlated to ring size and core geometry of the ligand and the atomic radius, oxidation state, coordination geometry and coordination n transactinium metal ion. These chelating agents may have certain applications to the solution of some radioactive waste problems if they can be attached to polymer supports and used to chemically separate the radioactive components in waste.

An "expanded porphyrin" ligand used in our study is called Alaskaphyrin. Recently, Sessler et al. reported the synthesis and structural characterization of a uranium "expanded porphyrin" complex (hexadentate pyrrole-derived uranyl(VI) Schiff-base complex) using alaskaphyrin. ${ }^{1}$ To date, we have been working towards the preparation of new alaskaphyrin complexes with $\mathrm{Th}(\mathrm{IV}), \mathrm{Np}(\mathrm{V})$ and $\mathrm{Pu}(\mathrm{VI})$. These metal species cover a range of oxidation states $(4,5$ and 6$)$ and ionic radii of $0.94,0.75$ and $0.71 \AA$, respectively. ${ }^{2}$ Results from these three metal species should provide us with knowledge on the dependence of complex formation on atomic radius, oxidation state and coordination geometry.

Several attempts to form the Th-alaskaphyrin complex suggest that the ionic radius of Th (IV) is too large for the formation of this complex. Reactions have also been carried out to form the $\mathrm{Np}$ - and the $\mathrm{Pu}$ alaskaphyrin complexes and the absorption spectra of the products (Fig. 1) indicate the formation of the new complexes. We are in the process of characterizing the products using NMR and IR spectroscopy. Both 
products have gone through a rigorous purification process in order to obtain single crystals for X-ray crystallography analysis. We have obtained several needle like single crystals of the Pu-complex. Although the crystals are of high quality and purity, they are too thin in one of the three dimensions for $\mathrm{X}$-ray analysis. Immediate plans focus on obtaining single crystals large enough for $X$-ray crystallorgrphic analysis.

Our results indicate that the formation of these complexes has a strong dependence on ionic radii. Th(IV), the largest of the cations, does not form a complex, however, $\mathrm{U}, \mathrm{Np}$ and $\mathrm{Pu}$ with ionic radii within a few hundredths of angstrom of each other all show complex formation. Results from X-ray crystallographic analysis should provide us with information on the specific coordination number and geometry of $\mathrm{Np}$ and $\mathrm{Pu}$ complexes which can be compared to the known $\mathrm{U}$ data.

\section{References:}

${ }^{1}$ T. D. Mody, J. L. Sessler, V. Lynch, Inorg. Chem., 31, No. 4, 529-31(1992).

2R. D. Shannon, Acta Cryst., A32 (1976) 751. 


\begin{tabular}{|c|c|c|}
\hline Species & CR (A) & IR (A) \\
\hline Th (IV) & 1.04 & 0.94 \\
\hline $\mathrm{U}(\mathrm{IV})$ & 1.03 & 0.89 \\
\hline $\mathrm{U}(\mathrm{VI})$ & 0.87 & 0.73 \\
\hline $\mathrm{Np}(\mathrm{IV})$ & 1.01 & 0.87 \\
\hline $\mathrm{Np}(\mathrm{V})$ & 0.89 & 0.75 \\
\hline $\mathrm{Np}(\mathrm{VI})$ & 0.86 & 0.72 \\
\hline $\mathrm{Pu}(\mathrm{IV})$ & 1.00 & 0.86 \\
\hline $\mathrm{Pu}(\mathrm{V})$ & 0.88 & 0.74 \\
\hline $\mathrm{Pu}(\mathrm{VI})$ & 0.85 & 0.71 \\
\hline
\end{tabular}

Table 1. Crystal radius (CR) and effective ionic radive (IR) for some actinide species. 


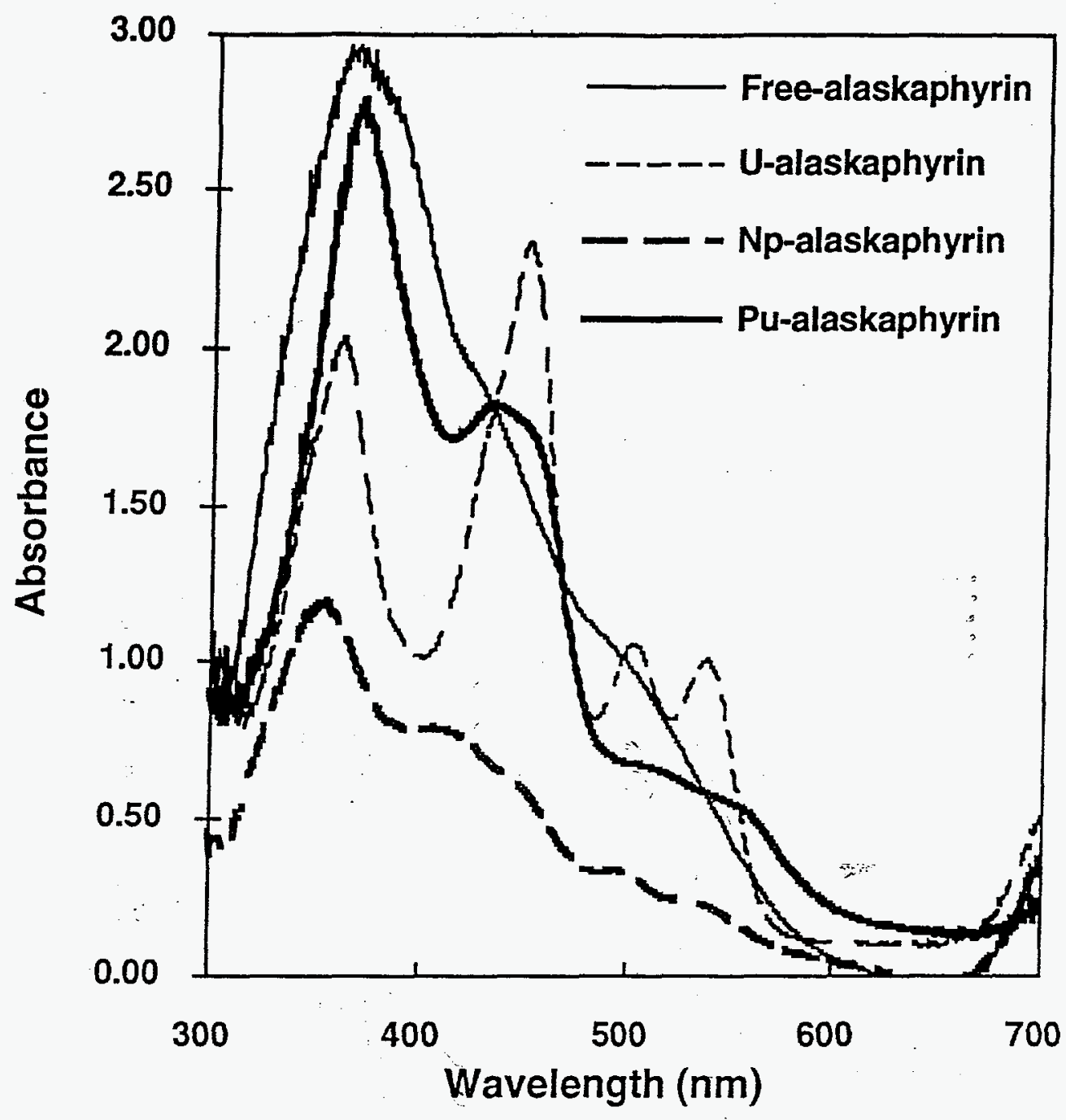

Figure 1

A comparison of the absorption spectrum for the free-alaskaphyrin, the $\mathrm{U}-, \mathrm{Np}$-and the Pu-complex. 